\title{
3D models related to the publication: The first French tragulid skull (Mammalia, Ruminantia, Tragulidae) and associated tragulid remains from the Middle Miocene of Contres (Loir-et-Cher, France)
}

\author{
Mennecart Bastien ${ }^{1 *}$, de Perthuis Adrien², Costeur Loïc ${ }^{1}$ \\ ${ }^{1}$ Naturhistorisches Museum Basel, Switzerland, $\mathrm{CH} 4001$ \\ ${ }^{2} 27$ rue des Papegaults, 41000 Blois, France \\ *Corresponding author: mennecartbastien@gmail.com
}

\begin{abstract}
This contribution contains the 3D models described and figured in the following publication: Mennecart $B$., de Perthuis Ad., Rössner G.E., Guzmán J.A., de Perthuis Au., Costeur L. The first French tragulid skull (Mammalia, Ruminantia, Tragulidae) and associated tragulid remains from the Middle Miocene of Contres (Loir-et-Cher, France). Comptes Rendus Palévol. https://doi.org/10.1016/j.crpv.2017.08.004
\end{abstract}

Keywords: comparative anatomy, CT-scan, ear region, MN5, systematics

Submitted:2017-06-30, published online:2017-11-23. https://doi.org/10.18563/m3.3.3.e4

$\begin{array}{llc}\text { Inv. nr } & \text { Taxon } & \text { Collection } \\ \text { NMBFa.213.abg } & \text { Dorcatherium crassum } & \text { NMB, } \\ & & \text { Basel }\end{array}$

Table 1. Information related to the 3D model, a fragmented skull with well-preserved basicranial areas. The 3D surface files of the specimen AP2014.0715 (digital copy NMB Fa.213.abg) are the reconstructions of the main skull fragments, the right petrosal bone, and the left bony labyrinth.

\section{INTRODUCTION}

We report the first skull of tragulid from France (see Fig. 1, Mennecart et al. 2017). The ear region is well-preserved. Thus, comparisons of this area are done with other living and extinct ruminants. Mennecart \& Costeur (2016a, b, c) already published in detail bony labyrinths and petrosal bones of living and fossil tragulid. Mennecart \& Costeur (2016b) and Mennecart et al. (2016) highlighted the importance of this structure in phylogenetic analyses, at least in ruminants. Here we confirm that the petrosal bone described in Mennecart \& Costeur (2016b, c) belongs to Dorcatherium crassum and that the ear region can be used for taxonomic purposes.

\section{METHODS}

The 3D surfaces were extracted within AVIZO 9 Lite (Thermo Fisher Scientific) using the segmentation threshold selection tool. The 3D surface models are provided in .ply format, and can therefore be opened with a wide range of freeware.

\section{ACKNOWLEDGEMENTS}

Grant sponsor: Swiss National Science Foundation. Grant number: 200021 159854/1

\section{BIBLIOGRAPHY}

Mennecart, B., Costeur, L. 2016a. Shape variation and ontogeny of the ruminant bony labyrinth, an example in Tragulidae. Journal of Anatomy 229(3), 422-35. https://doi.org/10. 1111/joa.12487

Mennecart, B., Costeur, L. 2016b. A Dorcatherium (Mammalia, Ruminantia, Middle Miocene) petrosal bone and the tragulid ear region. Journal of Vertebrate Paleontology 36(6), 1211665(1)-1211665(7). https://doi.org/10.1080/02724634 .2016 .1211665

Mennecart B., Costeur L. 2016c. 3D models related to the publication: A Dorcatherium (Mammalia, Ruminantia, middle Miocene) petrosal bone and the tragulid ear region. MorphoMuseuM 2 (1)-e2. https://doi.org/10.18563/m3.2.1.e2

Mennecart B., de Perthuis Ad., Rössner G.E., Guzmán J.A., de Perthuis Au., Costeur L. (online) The first French tragulid skull (Mammalia, Ruminantia, Tragulidae) and associated tragulid remains from the Middle Miocene of Contres (Loiret-Cher, France). Comptes Rendus Palévol. https://doi.org/ 10.1016/j.crpv.2017.08.004

Mennecart, B., Rössner, G.E., Métais, G., DeMiguel, D., Schultz G., Müller, B., Costeur, L. 2016. The petrosal and bony labyrinth of Early to Middle Miocene European deer (Mammalia, Cervidae) reveal their phylogeny. Journal of Morphology 277, 1329-1338. https://doi.org/10.1002/jmor. 20579 


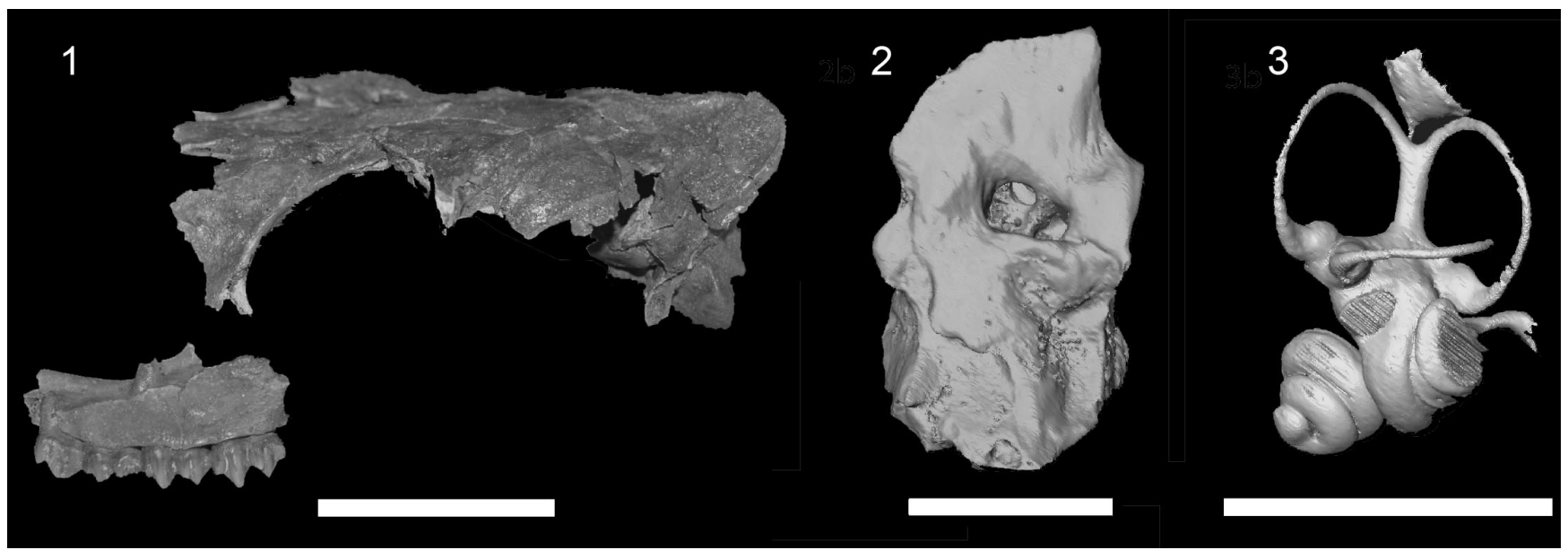

Figure 1. Skull of Dorcatherium crassum from Contres (original specimen AP2014.0715 and digital copy NMB Fa.213.abg). 3D reconstruction of the skull in left lateral view (1), right petrosal bone dorsomedial view (2), and left bony labyrinth ventrolateral view (3). Scale bare is $5 \mathrm{~cm}$ for 1 and $1 \mathrm{~cm}$ for 2 and 3 . 